\title{
Spawanie stali Hardox w wybranych osłonach gazowych
}

\author{
Welding of Hardox steel in selected gas shield
}

\section{Streszczenie}

W pracy przedstawiono wyniki badań nieniszczących oraz badań własności mechanicznych, udarności, twardości i makrostruktury złączy spawanych ze stali Hardox wykonanych metodą MAG w różnych osłonach gazowych.

Słowa kluczowe: spawanie; osłona gazowa; własności złączy spawanych

\section{Wstęp}

Stale Hardox są to wysokojakościowe stale o dużej odporności na ścieranie, dobrych własnościach mechanicznych oraz odporności na obciążenie udarowe [1]. Stale te charakteryzują się również dobrą spawalnością [2], przy czym bardzo ważny jest dobór energii liniowej spawania, materiałów dodatkowych, temperatury podgrzania wstępnego i międzyściegowej oraz prawidłowy dobór gazu osłonowego [3].

Gazy osłonowe, oprócz ochrony łączonych elementów przed wpływem tlenu, azotu i wodoru z powietrza, powinny także pozwolić na utrzymanie stabilnego łuku przy stosunkowo niskim napięciu, zapewnić uzyskanie dobrego wtopienia i gładkiego lica.

Stale Hardox spawa się na ogół metodą MAG w osłonie mieszanek gazowych $-\mathrm{Ar}+\mathrm{CO}_{2}$ lub $\mathrm{Ar}+\mathrm{CO}_{2}+\mathrm{O}_{2}$. Mieszanki gazowe poprawiają stabilność jarzenia się łuku, zmniejszają rozprysk, zwiększają wydajność spawania, poprawiają jakość spoiny i na ogół własności mechaniczne złączy spawanych [4]. Gazy osłonowe wpływają na kształt słupa łuku oraz charakter transportu kropli ciekłego metalu. Dodatek dwutlenku węgla polepsza formowanie i kształt spoiny oraz zwiększa wtopienie. Dodatek tlenu, z kolei, powoduje zmniejszenie wartości prądu krytycznego, co sprzyja transportowi drobnokroplowemu i pozwala, w stosunku do osłony z czystego argonu, na stosowanie większej średnicy drutu elektrodowego lub, przy tej samej średnicy, na spawanie cieńszych blach. Tlen w mieszance polepsza formowanie ściegów, zmniejsza porowatość i rozprysk, a także powoduje wzrost wydajności spawania. Dodatek tlenu do mieszanki $\mathrm{Ar}+\mathrm{CO}_{2}$ poprawia wydajność spawania i stabilność jarzenia się łuku, sprzyja lepszemu formowaniu spoiny, a także pozwala ograniczyć zawartość wodoru i azotu w stopiwie [5].

Efektywność osłony gazowej zależy od własności fizycznych i chemicznych gazów, a także od wielu czynników technologicznych, m.in.: wydatku gazu, natężenia prądu spawania, pozycji spawania, rodzaju złącza, kąta nachylenia dyszy gazowej uchwytu [2].

\section{Abstract}

The paper presents the results of non-destructive tests and mechanical properties, toughness, hardness and macrostrucure tests of welding joints of Hardox steel, welded in various gas shields.

Keywords: welding; gas shield; properties of welding joint

\section{Badania własne}

Badaniom poddano cztery płyty próbne o wymiarach 150 x 280 mm i grubości 10 mm ze stali HARDOX 400 o składzie chemicznym i własnościach mechanicznych podanych w tablicy I.

Tablica I. Skład chemiczny i własności mechaniczne stali Hardox 400 Table I. Chemical composition and mechanical properties of Hardox 400 steel

\begin{tabular}{|c|c|c|c|c|c|c|c|c|}
\hline \multicolumn{9}{|c|}{ Skład chemiczny stali [\%] } \\
\hline C & Si & $\mathrm{Mn}$ & $P$ & $S$ & $\mathrm{Cr}$ & $\mathrm{Ni}$ & Mo & B \\
\hline 0,32 & 0,70 & 1,60 & 0,025 & 0,010 & 1,40 & 1,50 & 0,60 & 0,004 \\
\hline \multicolumn{9}{|c|}{ Właściwości mechaniczne } \\
\hline \multicolumn{3}{|c|}{$\mathrm{R}_{\mathrm{m}}, \mathrm{MPa}$} & \multicolumn{2}{|c|}{$\mathrm{R}_{\mathrm{e}}, \mathrm{MPa}$} & \multicolumn{2}{|c|}{ Udarność, J } & \multicolumn{2}{|c|}{ Twardość, HB } \\
\hline \multicolumn{3}{|c|}{1200} & \multicolumn{2}{|c|}{1000} & \multicolumn{2}{|c|}{45} & \multicolumn{2}{|c|}{$370-430$} \\
\hline
\end{tabular}

Spawanie prowadzono metodą MAG (135) w pozycji podolnej, prądem stałym biegunowości dodatniej. Zastosowano drut GMnNi3CrMo o średnicy 1,2 mm oraz cztery osłony gazowe o następującym składzie chemicznym:

1. $\mathrm{Cl}\left(100 \% \mathrm{CO}_{2}\right)$;

2. $\mathrm{M} 21\left(82 \% \mathrm{Ar}+18 \% \mathrm{CO}_{2}\right)$;

3. $\mathrm{M} 12\left(97,5 \% \mathrm{Ar}+2,5 \% \mathrm{CO}_{2}\right)$;

4. $\mathrm{R} 1\left(98 \% \mathrm{Ar}+2 \% \mathrm{H}_{2}\right)$.

We wszystkich przypadkach przepływ gazu osłonowego wynosił $12 \div 18 \mathrm{l} / \mathrm{min}$, prąd spawania $160 \div 240 \mathrm{~A}$, napięcie $20 \div 27 \mathrm{~V}$, a prędkość spawania $15 \div 40 \mathrm{~cm} / \mathrm{min}$.

Po przeprowadzeniu procesu spawania, złącza poddano badaniom nieniszczącym: wizualnym, penetracyjnym i radiograficznym oraz badaniom niszczącym, obejmującym próby rozciągania, udarności, zginania, badania twardości i makrostruktury.

Dr inż. Anna Pocica - Politechnika Opolska, inż. Tomasz Buszyński - Spawex Anna Buszyńska.

Autor korespondencyjny/Corresponding author. a.pocica@op.opole.pl 
Tablica II. Własności mechaniczne złączy spawanych

Table II. Mechanical properties of welded joints

\begin{tabular}{|c|c|c|c|c|c|}
\hline \multirow{2}{*}{ Oznaczenie próbki } & \multirow{2}{*}{$\begin{array}{c}\text { Wytrzymałość } \\
\text { na rozciąganie } R_{m}, M P a\end{array}$} & \multicolumn{2}{|c|}{ Udarność, J } & \multicolumn{2}{|c|}{ Próba zginania } \\
\hline & & lico & grań & lico & grań \\
\hline $\mathrm{Cl}\left(100 \% \mathrm{CO}_{2}\right)$ & 885 & 33 & 18 & pozytywny & negatywny \\
\hline M21 (82\%Ar+18\% CO $\mathrm{CO}_{2}$ & 878 & 34 & 19 & pozytywny & negatywny \\
\hline $\operatorname{M} 12\left(97,5 \% \mathrm{Ar}+2,5 \% \mathrm{CO}_{2}\right)$ & 856 & 51 & 38 & pozytywny & negatywny \\
\hline $\mathrm{R} 1\left(98 \% \mathrm{Ar}+2 \% \mathrm{H}_{2}\right)$ & 785 & 23 & 16 & pozytywny & negatywny \\
\hline
\end{tabular}

Badania wizualne prowadzono zgodnie z normą PN-EN ISO 5817, przy użyciu standardowego wyposażenia. Badania penetracyjne wykonano $\mathrm{w}$ temperaturze $20^{\circ} \mathrm{C}$ stosując penetrant barwny. Blachy przed próbą czyszczono mechanicznie. Po nałożeniu penetrant wnikał w złącze przez $20 \mathrm{~min}$, po czym powierzchnie zmywano i nakładano wywoływacz.

Badania radiograficzne przeprowadzono zgodnie z wytycznymi norm PN-EN ISO5817, PN-EN ISO 10675-1, PN-EN ISO 5579 i PN-EN ISO 17636-1. Źródłem promieniowania było urządzenie ERESCO 52MF4-CL. Natężenie prądu wynosiło 4,0 mA, a odległość źródło - błona $700 \mathrm{~mm}$. Zastosowano okładki wzmacniające przód $\mathrm{Pb} 0,05$ i tył $\mathrm{Pb} 0,15$. Wszystkie badania nieniszczące wykazały, że złącza mają klasę jakości B.

Badania wytrzymałości na rozciąganie przeprowadzono na zrywarce ZD 40 zgodnie z PN-EN ISO 4136. Temperatura badania wynosiła $23^{\circ} \mathrm{C}$, a dokładność wskazania zrywarki $2 \mathrm{kN}$.

Badania udarności prowadzono ma młocie Charpy`ego w temperaturze $-20{ }^{\circ} \mathrm{C}$, na znormalizowanych próbkach z karbem typu $\mathrm{V}$.

Próbę zginania prowadzono od strony grani i od strony lica. Próbkę podparto na wałkach i obciążono siłą F. Kąt zginania wynosił $180^{\circ} \mathrm{i}$ jeżeli po zginaniu nie stwierdzono wad zewnętrznych wynik uważano za pozytywny.

Wyniki badań własności mechanicznych złączy przedstawiono w tablicy II.

Badania twardości wykonano metodą Vickersa przy obciążeniu 100 N. Pomiary wykonano w dwóch liniach i obejmowały one materiał rodzimy, strefę wpływu ciepła i spoinę. Wyniki pomiarów przedstawiono na rysunku 1.

\section{Analiza wyników badań i wnioski}

Spawanie stali Hardox metodą MAG w różnych osłonach gazowych pozwala na uzyskanie prawidłowych złączy o poziomie jakości B. Wyjątek stanowi spoina wykonana w osłonie mieszanki $\mathrm{R} 1-98 \% \mathrm{Ar}+2 \% \mathrm{H}_{2}$, w której występują pod-

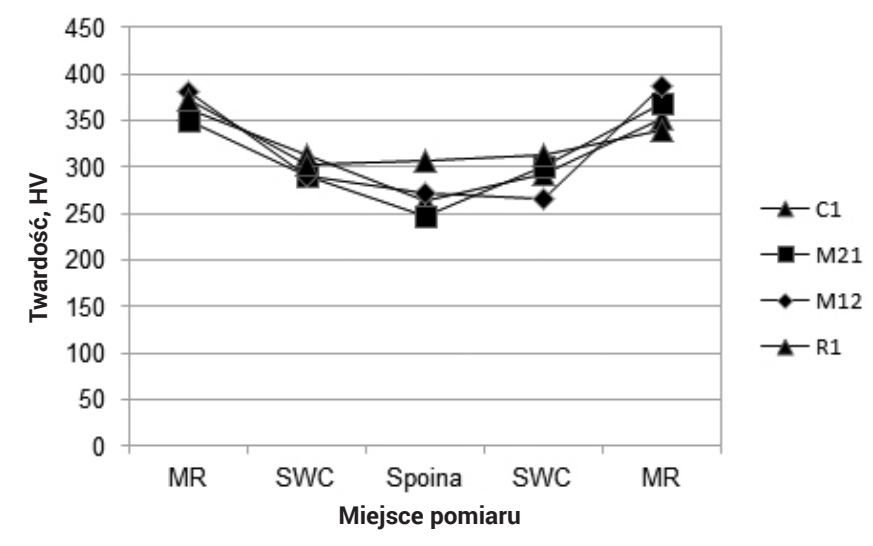

Rys. 1. Rozkład twardości w przekroju poprzecznym badanych złączy Fig. 1. Hardness distribution in cross-section of tested joints

topienia w licu i grani. Tego typu niezgodności nie obserwuje się w innych złączach.

Spoina wykonana w osłonie R1 ma najniższą wytrzymałość i jednocześnie najmniejszą udarność. Twardość spoiny oraz SWC jest natomiast największa.

Najlepsze własności plastyczne można uzyskać dla spawania w osłonie $\mathrm{Ar}+\mathrm{CO}_{2}$, przy czym udarność od strony lica jest większa niż od strony grani. Gorsze własności od strony grani potwierdza próba zginania, w której dla wszystkich złączy uzyskano wynik negatywny. Jest to spowodowane niedostateczną osłoną gazową tego obszaru, a także utwardzeniem spoiny w wyniku szybkiego odprowadzenia ciepła.

Spawanie w czystym $\mathrm{CO}_{2}$ pozwala uzyskać największą wytrzymałość złącza, lecz w metodzie tej występuje duża ilość rozprysków i znaczne umocnienie w strefie wpływu ciepła. Trzeba sobie zdawać sprawę z tego, że trudno jednoznacznie uzależnić własności złącza od jednej zmiennej. Każdorazowo więc należy analizować wszystkie zmienne (prąd, napięcie, szybkość spawania, osłona gazowa) i dopiero na podstawie takiej analizy możliwe jest określenie zalecanych parametrów spawania czy osłony gazowej.

\section{Wnioski}

Na podstawie przeprowadzonych badań sformułowano następujące wnioski

1. Wszystkie złącza, bez względu na zastosowaną osłonę gazową mają klasę jakości B.

2. Własności od strony lica są wyższe niż od strony grani, co jest związane z warunkami krzepnięcia spoiny i niedostateczną osłoną tego obszaru.

3. Spawanie w osłonie $98 \% \mathrm{Ar}+2 \% \mathrm{H}_{2}$ powoduje wystąpienie podtopień w licu i grani spoiny, a spoina ma najniższe własności mechaniczne.

\section{Literatura}

[1] Dudziński W., Konat Ł., Pękalska L., Pękalski G.: Struktury i właściwości stali Hardox 400 i Hardox 500, Inżynieria Materiałowa, nr 3, s. 139-142, 2006.

[2] Konat Ł.: Struktury i własności stali Hardox a ich możliwości aplikacyjne w warunkach zużywania ściernego i obciążeń dynamicznych, Praca doktorska, Wrocław, 2007.

[3] Spawanie trudnościeralnych stali Hardox, https://www.ssab.pl/produkty/ marki/hardox/pl-spawanie-artykul
[4] Pierożek B., Lassociński J.: Spawanie łukowe stali w osłonach gazowych, WNT, Warszawa, 1997.

[5] Pocica A., Popanda W., Nowak D.: Badania spoin wykonanych metodą MAG w różnych osłonach gazowych, Przegląd Spawalnictwa nr 5, s. 59-63, 2014.

[6] Ferenc K., Ferenc J.: Spawalnicze gazy osłonowe i palne, WNT, Warszawa, 2005. 